(C) 2016

\title{
The Democratic Duty to Oppose Brexit
}

\section{Albert Weale \\ Emeritus Professor of Political Theory and Public Policy, School of Public Policy, University College London (a.weale@ucl.ac.uk)}

Text of a lecture delivered to the Policy and Practice Seminar, School of Public Policy, University College London on Thursday 8 December 2016. This text may be reproduced in whole or in part provided the source is acknowledged.

\section{Introduction}

The proposition that I put to you today is that there is democratic duty to oppose Brexit. Let me be more precise. Suppose that you are a UK citizen. Suppose that you believe that it would be a serious mistake for the UK to leave the European Union, because it would do profound damage to the common good of UK society. Suppose finally that you are a convinced democrat, firmly committed to the values and the principles of democracy. Then, given these three conditions, you have a duty to oppose Brexit.

This proposition swims against the tide of much contemporary commentary, and not only among Brexiteers. Many MPs who were in favour of remaining, have nonetheless accepted that the referendum result creates an obligation to implement the decision, as both the debate and the vote on the House of Commons opposition motion last night goes to show. My own MP, Heidi Allen not someone who is afraid of taking an independent stand, has written that while she fully accepts that many of her constituents (who voted by a large majority to remain) find the result disappointing, 'we cannot now ignore the vote because we don't like the result." Among many of those who were passionately convinced that Remain was the right option, there is a belief that to continue the campaign is somehow to betray democratic values. They wish the result had been otherwise, but given how the referendum turned out, the task is to make the best of a bad job and ensure that the UK can get the most advantageous deal possible on leaving the EU. Those holding this view like to think that if the result had gone the other way, then the Brexiteers would have accepted it, and so in fairness they feel that they should accept losing as best they can. British stoicism combines with presumed democratic principle to produce resignation.

As you would expect, among confirmed Brexiteers, the view that there is a duty to implement the result of the referendum is even stronger. For them, the referendum is the end of the matter. They believe that those who continue to oppose Brexit are the Remoaners. They are bad losers. They are elitists, whose opposition to the result of the referendum displays contempt for the ordinary wisdom of the common citizen. To oppose the will of the people is to oppose democracy as such. 
For those who hold either of these views, there is not even a right to oppose Brexit, let alone a duty. A right specifies what we may do; a duty specifies what we must do. When we have a right to express our views, it means that we may choose to express them if we want to, but also choose not to express them if we do not want to. To have a right to speak out is not to have an obligation to speak out. By contrast, when we have a duty to speak out, it means that we must speak out whether or not we want to. So, a claim of duty is stronger than a claim of a right. It is not true that what we may do, we always must do; it is true that what we must do, we must always do. Duties bind.

For many people it would be much more comfortable to believe that democratic principles require citizens, including Remainers, to accept the Brexit referendum result and not oppose the fundamentals of current government policy. How much more agreeable it is to be told that our democratic duty means that we can just get on with our private lives, cultivating our own gardens, without taking an unpopular stance against a decision that the country has already made.

If you are in this position of seeking peaceable agreement tonight, I bring you nought for your comfort. The principled questions posed by Brexit not only raise some of the most difficult and intricate issues in the theory of constitutional democracy, they also have personal - perhaps even existential - meaning for individuals. Like it or not, if you are a citizen of the United Kingdom, if you believe Brexit to be a profound mistake and if you are a true democrat, then you have a duty to oppose Brexit. To paraphrase Leon Trotsky on war: you may not be interested in Brexit; but Brexit is interested in you.

\section{If You Are A UK Citizen}

When I say that, if you are a UK citizen, then you have a duty to oppose Brexit, I am not making any inference as to what non-UK citizens should or should not do. It is an interesting question in democratic theory how far individuals or organisations are allowed to participate in the political processes of another country. If you are not a US citizen but you are a firm believer in the values of liberal humanism, are you allowed to contribute to campaigns to oppose the Trump presidency? If you are not a French citizen, what right do you have to participate in campaigns against the French National Front? In general, what standing does anyone have to take part in the debates and campaigns of another country? These are not easy questions to answer. The principles of collective self-government must exclude at some point those who are not members of the polity from seeking unduly to influence debate and discussion among those who are. Just as we (referring for the minute to UK citizens) might not want foreign interests interfering in our domestic politics, so we might impose a selfdenying ordinance upon ourselves in respect of participation in the public affairs of other countries.

In the case of the EU, of course, the situation is different and unique. EU citizens who are resident in the UK by virtue of their EU treaty rights may well be said to have a personal stake in what a UK government decides, even if they lack voting rights or are free of other obligations of citizenship. They have made a commitment to friends, family, work and 
community. They have planned their lives on the assumption that international treaties are meaningful and that the UK's obligations in respect of citizenship would not be lightly abrogated. It seems churlish to deny EU citizens at least the right to oppose Brexit. Citizens of the EU in general can also be said to have a legitimate interest in the decision. Yet, I know many EU citizens who have adopted a self-denying ordinance in respect of Brexit. They regret the decision, but they accept that it is a matter purely for UK citizens. Whether they are right to do so, I do not know. I feel enormous sympathy with the position of EU residents in the UK, but I do not have a well-worked out set of principles by reference to which I can make a fair judgement about their political rights and responsibilities in respect of Brexit.

So my argument tonight is directed solely to UK citizens. As political theorists say, the obligations that I am discussing are associative obligations. They are obligations that arise as a result of being a member of a particular political association, the United Kingdom in 2016. They are local obligations, not the humanitarian obligations that we might have as citizens of the world. (By the way, it is not clear to me why Therese May at the Conservative Party conference was so disparaging of that ancient Stoic category of cosmopolitan citizenship - an essential concept in the civilising of human nature - but that is another matter.) Today I am solely discussing the duties of citizens of the United Kingdom, the obligations of those on whom chance or choice has bestowed UK citizenship.

\section{If You Believe Brexit to be A Mistake}

If the first condition that you have to satisfy in order to have a duty to oppose Brexit is that you are a citizen of the UK, the second depends on your thinking that the decision to leave the European Union is a mistake, a mistake so serious that it threatens the common good of UK society.

This is not the occasion on which to rerun the arguments that were put forward during the referendum campaign, let alone the arguments that should have been put forward during that campaign. However, since believing Brexit to be a mistake is an important step in the case I make today, it is necessary at least to recapitulate some of those arguments.

There are many reasons why someone might believe Brexit to be a mistake, but I shall refer to just four:

1. You might believe that Brexit is economically damaging.

2. You might believe that the principle of 'taking back control' was based on a false characterisation of the pooling of sovereignty that membership of the European Union involves.

3. You might believe that the European Union offers opportunities of political cooperation that promote the common good of its constituent countries.

4. You might believe that the European Union provided the framework for democratic consolidation in Europe.

You can hold to all of these propositions and acknowledge legitimate concerns about migration. 
Let me turn first to the argument that Brexit will be economically damaging. The starting point here is a form of policy conservatism, holding that it is imprudent, to say the least, to forgo membership of a single market of some 500 million people accounting for some $45 \%$ of the UK's exports in exchange for the speculative advantages of global free trade. You might think that being outside the EU's common external tariff is too big a gamble to take for the economy. You might think that the vision of the UK economy as one that produces domestically and sells internationally ignores the growth of supply and production chains that are increasingly inter-dependent across international borders and that the gravity effects of trade relations - the tendency of economies that are geographically close to one another to trade more intensively than with those who are distant - provide a powerful reason for staying in the EU. You might think that when a distinguished Brexit economist says that the proper policy response to leaving the EU means that - and I quote precisely - 'we would mostly eliminate manufacturing, leaving mainly industries such as design, marketing and hitech. But this shouldn't scare us.', that on the contrary we should be scared. ${ }^{2}$ You might think that international free trade under WTO rules has been relatively successful for goods, but not for services and agriculture, two areas in which the UK has some comparative advantage. In short, you might think that the shock therapy of hard Brexit - no longer a member of the single market and outside the common external tariff - will not just fail to boost the UK economy but will seriously damage it. Even if patients survive shock therapy, the experience can still be permanently damaging.

But are we faced with hard Brexit as these suppositions seem to suggest? In its statement of 29 June, the European Council, having noted that it wished to have the UK as a close partner of the EU, also stated: 'Any agreement, which will be concluded with the UK as a third country, will have to be based on a balance of rights and obligations. Access to the Single Market requires acceptance of all four freedoms.' The four freedoms include, of course, the freedom of movement of workers. If we take the European Council at its word (and too few UK politicians do in my view), then there can be no membership of the single market without the free movement of workers. So, as long as a UK government sticks to its intention to bring down net migration to 'tens of thousands', then membership of the single market is precluded.

However, economics is not everything, and this brings me to my second point. Those favouring Brexit often argued a purely political case. The foot soldiers of the Leave campaign were concerned with something other than the economics of comparative advantage. 'Take back control' and 'we want our country back' are pre-eminently the principles of engaged democratic citizens. No one listening to their arguments could doubt their sincerity or their commitment. Many Leavers believed themselves to be fighting for a cause greater than the standard of living or the control of tariffs on goods and services. For them the single market was a mundane matter. Instead, they thought in terms of parliamentary representatives determining the common political life in the UK. They accepted that governments might bungle, but they wanted the right to cashier the bunglers through elections. They wanted to live under rules chosen by the people of the UK. They wanted democratic autonomy unconsciously echoing Pericles' famous praise of classical 
Athens: our system of government does not copy the institutions of our neighbours; it is more a case of our being a model to others than of our imitating anyone else.

But, what are we supposed to be taking back control from? The usual suggestion is being 'governed by Brussels'. However, 'being governed by Brussels' is a lazy journalistic slogan rather than a serious analysis of the balance of power and sovereignty in the European Union. It is not Brussels that has prevented successive UK governments from developing technical education and training to address the low levels of productivity in the economy. It is not Brussels that has dictated the pace and scale of public expenditure savings in the UK since 2010. It is not Brussels that has restricted policies to promote renewable energy. It is not Brussels that has forced expensive and counter-productive reforms upon the National Health Service. It is not Brussels that has constrained the UK from finding effective ways to finance social care for the elderly and disabled. It is not Brussels that has inhibited UK governments from investing in public goods like integrated public transport or internet access in rural areas. It is not Brussels that is driving the centralisation of control in UK universities. It is not Brussels that has led successive governments to fail in their regional policies.

I do not pretend that the solution to these policy problems - of technical education, of renewable energy, of the intermeshing of social care and health care or of the protection of our standards of higher education - is easy or without trade-offs, just as I do not assume that finding the right balance between controlling deficits in public spending and the maintenance of public goods and social services is easy. I merely make the point that on these issues, issues that are most salient to the UK electorate, saying 'take back control' is meaningless, because control has never been ceded. Exaggerating the loss of sovereignty serves as an excuse for the failures of successive UK governments.

Thirdly, you might think that leaving the European Union is a mistake because it has provided the framework within which policies in the common interests of democratic states could be pursued. The most obvious example is policies on the environment. Since the 1980s the European Union has provided the policy and political context within which stringent environmental rules have been developed, initially on air and water pollution, but also on species protection and ensuring that environmental concerns are integrated into a wide range of public policies. The most significant achievement of the European Union under this heading is climate change policy. Brexit threatens the solidarity that is essential to the European Union acting as one.

Fourthly, you might think that the European Union has been central to the consolidation of democracy in Europe and you might remember that it was the UK government that favoured the eastward expansion of the EU in the 1990s. With its 28 countries, there are currently more democracies in the EU than there were in the whole world in 1951 when the Coal and Steel Community was formed. Of those 28 countries, eleven have become democracies since the collapse of the Berlin wall in 1989, and three of them - Greece, Portugal and Spain since the collapse of the last vestiges of fascism in Europe in the 1970s. The EU now comprises the largest group of national democracies joined in political association that the world has ever known. Of course, the EU is not solely responsible for democratic consolidation in central and eastern Europe. The role of NATO has also been important. A 
military alliance of states, however, can only protect against territorial enemies. It cannot create the conditions for democratic consolidation, particularly in a part of the world that is still overcoming its historical legacy of imperial and authoritarian rule.

What then of immigration? This is an issue that should have been taken more seriously since 2004. There is too easy an assumption on the liberal-left of politics that to be concerned with immigration is to be racist. This is to deny what for some of our fellow citizens is the lived perplexity of the effects of migration. Let me take a stylised, but real, example. If you live in a northern town or city and you see Polish shops opening in streets that you have known since childhood, conducting their business in Polish and trading in Polish goods, you literally - literally - do not understand what is happening around you. If your perplexity is compounded by pressure on schools and hospitals and other public services, then you may well think that to solve your problems all you need to do is to control immigration.

In the context of these quite understandable anxieties, there has been a failure to spell out the facts and the trade-offs. Would people seeing these foreign shops opening really prefer that the shops were empty and boarded up? How does an 'Australian-style points system' deal with the need for relatively low skilled work in agriculture and the hospitality industry? What is the alternative: to bus the unemployed from Hartlepool down to East Anglia to pick the fruit and asparagus? If taking back control of immigration does not in practice mean reducing the numbers of migrants but allowing migration from around the world, how far does that address the anxieties? Of the 330,000 or so net migrants to the UK in any one recent year, just under half are from the EU. The bulk of the remainder are from outside the EU. Again, I do not suppose that there are simple answers in responding to the pressures of immigration, but it is precisely for that reason that I say that leaving the EU offers a simple slogan in response to a complex problem.

These are just some of the reasons why one might think that leaving the EU was a mistake. Note that all of these considerations have nothing to do with the character of those who advanced the Leave argument. I do not think, to quote the words of David Cameron on UKIP that those who voted to leave were 'fruitcakes, loonies and closet racists'. When I debate these issues with my Leave friends and acquaintances, I do not think that they have lost their senses or that they harbour ethnic cleansing ambitions. I just think that they are wrong.

Of course, my Brexit friends and acquaintances pay me the reverse compliment of thinking that I am wrong, and clearly both sides cannot be right. But this just means that all of us are under the burdens of judgement, arising the fact that in important political matters, complexity and uncertainty as to consequences makes it very hard to come to a fully justified political judgement. Yet being under the burdens of judgement should not induce passivity. Liberals, it is sometimes said, are people who cannot even take their own side in an argument. Even under the burdens of judgement, you have to take a position. The burdens of judgement are just that, burdens. And if the defence of a great cause does not involve the burdens of judgement, then it is not a great cause.

Note - and this is very important both practically and in terms of democratic theory - that the differences to which I am referring are differences of judgement not of mere preference. 
When my MP said that we may not like the result of the referendum but we should accept it, she appeared to make the whole question into a matter of likings and dislikings, as though one was voting for the celebrities on Strictly Come Dancing. Yet, democracy, rightly understood, is not simply a device for the registering of the preferences of individuals. It must also be the institutionalisation of a public discussion in which evidence, argument and persuasion have a central place.

\section{If You Are a Convinced Democrat}

Very well, I imagine you saying. You understand that there might be sound arguments favouring Remain, but, in a situation of political disagreement, there is still the need to make a decision. If the people are sovereign, then the right to make that decision belongs to the people, who expressed their will on 23 June 2016. Democracy needs argument, but it also needs decision, and the crucial decision was effectively made in June. Moreover, democrats should respect the result of the referendum as an expression of the popular will. Even if Remainers thought they had won the argument, they lost the vote, and the obligation to obey the popular will arises at just this point.

It is a feature of constitutional crises, like the one that the UK is currently undergoing, that they bring to the surface fundamental conceptual questions about the logic of constitutional order, questions concerning sovereignty, political representation and idea of the will of the people. You cannot have a clear view on the nature of the practical choices we face with in current affairs without having a clear view about these basic theoretical and conceptual questions. So what are the arguments for thinking that the referendum should be decisive?

One way of justifying the claim that there can be no opposition to the result of the referendum is to appeal to the principles of what I shall call, following Max Weber, plebiscitary democracy. This is not the only way to defend the authority of the referendum, and I shall come to a different set of claims later. But an appeal to the principles of plebiscitary democracy is, I think, relied upon both consciously and unconsciously in the public discussion of Brexit, and for that reason its claims need attention.

The theory of plebiscitary democracy can be expressed in three claims. Firstly, the people are sovereign. Secondly, the people as sovereign are entitled to express their will on matters of public policy through a referendum in which a simple majority is decisive. Thirdly, the function of the government is to implement the will of the people as decided by the referendum. As a corollary of these claims, it is argued, anything that frustrates the will of the people is simply anti-democratic. As a view of democracy, these claims are profoundly mistaken.

Begin with the claim that in a democracy it is the people who are sovereign. To justify this claim some theorists of democracy tell a simple story, one that seems at first sight to make sense in the light of European history. That story runs as follows. Once upon a time, the monarch was sovereign and the monarch's will formed the basis of political authority. With democratization, the will of the monarch was replaced originally by the will of representative 
bodies like parliaments and then by the will of the people themselves. So, democratic sovereignty now means that the people governs itself. Rousseau famously said that the British people thinks itself free, but it is mistaken. It is only free once every five years when it elects its representatives. Those defending plebiscitary democracy are echoing this populist account of democracy as articulated by Rousseau.

Yet, as H.L.A. Hart pointed out many years ago in The Concept of Law, the storyline on which this principle of popular sovereignty is based makes no logical sense. ${ }^{3}$ Citizens as members of a people cannot give orders to themselves, unless we assume that there is a set of accepted rules by which the results of elections and the processes for making laws are validly defined. If popular self-government means anything, it can only be defined by reference to a set of recognised rules. The very idea of popular self-government presupposes constitutional rules, and those rule can only be defined by political representatives. A people cannot govern itself directly without relying upon some underlying rules of the political game. Contrary to Rousseau, it is not that the British people is free only once every five years when it elects it representatives; rather it is free because its political representatives accept as an element of their procedures rules that make government accountable through elections.

We can see this essential constitutional role of political representatives if we look at the founding moments of political constitutions that proclaim the sovereignty of the people. Consider Germany's Basic Law of 1948, the preamble of which says that the Basic Law is formulated by the German people 'in the exercise of their constituent power'. In fact, the Basic Law was drawn up by political representatives drawn among others from the anti-Nazi parties of Germany. It was only later sanctioned by the electorate in a process designed by those representatives. Similarly, take the example of the United States, the constitution of which begins with the ringing claim that it is 'We the People of the United States' who ordain and establish the constitution, when in fact the constitution was drafted in Philadelphia in 1787 and only subsequently ratified by a process determined at that convention.

The United Kingdom until recently has avoided the fallacies associated with ideas of popular sovereignty because of the historic continuity of its constitution - the phenomenon of new wine in old bottles - resting on the principle of parliamentary sovereignty going back to the seventeenth century, a phenomenon nicely recapitulated in the recent judgement of the High Court on the Miller case. But my conceptual point is that there is a general truth lurking in this particular history, namely that the making of constitutional rules - the secondary rules that define the primary rules of legislation - can only be done by political representatives.

Let me suppose, however, that this argument cannot stand and that we can meaningfully talk about the sovereignty of the people. For the people to exercise its sovereignty, it would have to formulate its collective will. But what does the phrase 'the will of the people' really mean? There is obviously one condition under which the phrase the 'will of the people' would make clear sense, namely in conditions of complete unanimity. It was a form of unanimity that Rousseau, as the great theorist of popular sovereignty, imagined when he said that in a fully self-governing society someone only had to utter the general will, and everyone would immediately recognise it as valid. However, short of those conditions (in other words in any circumstance outside the more idealistic flights of fancy of political theorists), the idea 
of the popular will must depend for its meaning on a definition of what proportion of the people short of unanimity is taken to be decisive.

In the 2016 referendum, the proportion of the people who were taken to be decisive was that of a simple majority. That majority was taken to define the popular will. Now, is there any reason why a simple majority might be taken to stand for the will of the people? Is there any magic, you may ask, in the figure of $50 \%$ plus 1 ?

As it happens, under certain conditions, the answer to this question is yes. It can be shown through logical analysis that the rule of deciding issues by a simple majority is the only rule that satisfies certain intuitively reasonable requirements. ${ }^{4}$ In particular, simple majority rule gives each and every voter an equal voice without biasing the decision making process towards the status quo, or any other alternative. So, all voters are treated equally and all alternatives are on a par. If you want to treat voters equally and you do not want to give a privileged place to any one alternative, then the only rule that you can use - at least if you are considering a choice involving two alternatives - is that of the simple majority. Any other rule will bias the collective choice in favour of particular individuals or in favour of particular alternatives. In short, so this argument runs, if you are a committed democrat, you believe in political equality. If you believe in political equality, then, short of unanimity, majority rule seems to encapsulate the principle of political equality. And, that being the case, majority rule gives us a plausible interpretation of the idea of the popular will.

Taken in this form, the argument would seem to bolster the claims of the Leave campaign that the referendum result should be authoritative for Remain voters. But there is a catch. The demonstration of the close connection between political equality and the majority principle presupposes that the issues over which a choice is being made are well-defined. As such the argument cannot be applied to the referendum vote on Brexit. 'Leave' was never, and in the nature of the case, cannot be one alternative. It is a portmanteau term for a number of mutually inconsistent alternatives, as is now becoming painfully clear as the UK government struggles to determine whether it should aim for soft Brexit, hard Brexit, grey Brexit, red white and blue Brexit, Brexit à la carte, Brexit whilst retaining membership of the single market, Brexit as a member of the customs union, full Brexit with WTO status, Brexit with or without a budget contribution and so on.

Once we break apart the Leave alternative into its component elements, we can see that a majority for Leave does not necessarily express anything like a popular will in respect of any one of those alternatives. Just consider two examples. Suppose - though I agree it currently seems unlikely - that the result of the Article 50 negotiations is that we are offered similar terms to that which Norway currently has with full membership of the single market, subject to the jurisprudence of the CJEU and with a budgetary contribution, but without a formal role in the making of the rules. What would majority opinion be on that alternative when pitched against the Remain status quo? We will never know unless the option is put to the British voting public. However, it is not unreasonable to suppose that many who formerly wanted to leave the EU, when faced with the choice between Remain and the Norway option, would prefer to stay, reasoning that at least the UK, unlike Norway, would have a say in the making of the rules. Similarly, suppose that the negotiations end in the hardest form of Brexit, with 
the UK outside the single market, the customs union and trading with the EU under yet to be negotiated WTO terms. What would the majority decide in respect of that alternative against the status quo? Unless the vote is put, we shall not know, but again it is not unreasonable to think that a majority would favour the status quo. In fact, it is possible that Remain pitched against any of the feasible but mutually exclusive alternatives would defeat each one of them. (It would be what voting theorists call a 'Condorcet-winner'.) The 'Leave' alternative bundles up mutually inconsistent options as though they were one option, when in fact they are several. Herein lies the origin of the powerful incantation: 'Brexit means Brexit, but what does Brexit mean?' And the answer is that it means one, but only one, of the feasible alternatives that were never placed singly before the electorate in the referendum.

What then should we conclude? The answer is that we really cannot sensibly and intelligibly use the language of the will of the people in respect of the referendum result. Even if majority voting were taken to be the best way of discovering the popular will, the 2016 referendum result would not meet the conditions for validly claiming that the popular will had been expressed. This is quite apart from any disquiet that people may have expressed about the way in which the campaign was conducted. Even if the campaign had been conducted with scrupulous attention to fact and logic, the way in which the alternatives were framed precludes an inference to a popular will established by majority voting.

None of this is to deny that referendums can play a unique and valuable role in democracies, particularly in matters of secession or political union. It is to say that their role can only be defined through the representative institutions and constitutional procedures by which they are established. In this sense they are creatures of statute, and they derive such authority as they have from the authority that bestows their powers. Their reach and significance is never self-interpreting.

However, to support a duty not to oppose the 2016 referendum result, you do not have to believe in the theory of plebiscitary democracy and the concepts of the sovereignty of the people and a popular will defined by majority voting. Although I think that many who do criticise Remainers in fact believe in something like the principles of plebiscitary democracy, I accept that there is no necessity for them to do so. There is a more modest line of argument in favour of taking the referendum as grounds for acceptance, which runs as follows.

The referendum was duly authorized by parliament. The 2015 European Union Referendum Act was passed in order to make provision for holding a referendum on membership of the European Union among the citizens of the United Kingdom and Gibraltar. The original bill received parliamentary assent, and there are no grounds for saying that the administration of the referendum did anything other than the implement the decision of parliament. On these grounds, it might be argued, the result of the referendum should not be opposed. It is the result of a process authorized by parliament as the body entitled to make decisions on matters concerning public policy in a case where parliament has chosen to defer to the electorate.

Anyone holding this position can also point out that, in the case of the EU referendum, the key clause simply stated that 'a referendum will be held'. It would have been perfectly possible for parliament to have stipulated some minimum threshold turn-out or a minimum 
super-majority, as has happened with previous referendums. Parliament did not, and so we can infer that it intended a simple majority in the referendum to be decisive. No one doubts that the statute that established the referendum was validly made, and so has authority.

I note in passing that this line of argument is quite distinct from the issues currently being argued in the Supreme Court about whether parliamentary approval is needed to trigger Article 50 or whether that triggering can take place under the royal prerogative. Despite the wilder headlines of the Brexit press, legal representatives for Miller have gone out of their way to argue that the case is not about whether the referendum should be acted on, but how it is to be acted on. So, on the purely legal question of whether the 2015 Act is valid statute law, there is no dispute.

However, the broader question for democratic theory is: what type of political obligations does a lawful statute imply? If one thing is clear in democratic theory, it is that there is no obligation to refrain from campaigning against or opposing a piece of legislation that has been validly adopted. There is no democratic obligation simply to accept the result of a referendum established by statute, since there is no obligation to give up campaigning against and opposing a political outcome with which you disagree. To suppose that there is such an obligation that would imply that there is no right to campaign for a change of legislation or change in government policy. Consider any controversial piece of legislation. As an example, I offer you the legislation establishing the Community Charge (the Poll Tax). Here was a piece of legislation that had appeared in the Conservative Party manifesto of 1987. That election produced a Tory landslide with 376 MPs (only 21 down on their numbers in 1983 ) with a popular vote of $43.4 \%$ (up from their popular vote of $42.4 \%$ in 1983). The Local Government Finance Bill received the royal assent on 29 July 1988. Suppose someone in 1988, when that legislation was passed, proposed that there was no longer any right to continue to oppose it. That would be the analogy of saying that there was a democratic obligation to accept the result of the referendum. After all, the legislation was duly made by act of parliament and the government of the day had made the proposal in its 1987 manifesto. Then the campaigns that led to its repeal some two years later would have been undemocratic. But of course they were not and the reason why they were not is quite simple. Democracy is not ultimately a matter of majority rule, but of institutionalised government and opposition.

In the UK's parliamentary democracy, no parliament can bind its successors. The 2015 UK Referendum Act cannot be taken to lay down obligations lasting into the indefinite future. Indeed, in the case of the UK's withdrawal from the EU, there is a good argument for not taking the referendum result to be even a short-term guide to obligations. Suppose, as seems likely, that the process of the UK leaving the EU is completed by March 2019, even if the UK accepts residual obligations under the negotiated terms. Suppose also that the terms of our leaving are not favourable and the consequences of leaving do not bear out the optimistic forecasts of the Brexiteers. Suppose, in fact, that leaving turns out to be the mistake that many think it will be, and that membership of the EU comes to be seen as the best security for the UK in an uncertain and fractious world. Suppose in those circumstances that a future parliament wished to reverse the decision to leave. Then the only way back into the EU for 
the UK would be an application under Article 49, which would inaugurate a process that would ultimately impose many heavier obligations, including the obligation to join the Eurozone, than we have now.

There may be some people who look upon this prospect with equanimity. I do not. Even if the consequences of leaving fall far short of this pessimistic prospect, the social and economic adjustments that the UK will need to make after Brexit are likely to be as great as those made after the 1981 Conservative budget, which cut public expenditure at a time of recession. There are many points (not all, but a very large number) on which I disagreed with the policies pursued by the Thatcher governments. But Margaret Thatcher had one characteristic which deserves respect. She did not tell the electorate what she thought they wanted to hear. She told them what she thought they needed to hear, particularly about inflation and economic inefficiency. At present on the Brexit side no one is talking about the trade-offs and scale of adjustments in the UK economy and society that will be needed when it goes into a global free trade regime outside the EU. That task now falls to the Remain side.

\section{Then You Have a Duty to Oppose}

So far I have tried to show that there is no duty simply to accept the result of the referendum. It would only be possible to make sense of such a duty if you held to a mistaken theory of plebiscitary democracy or a theory of parliamentary sovereignty that precluded continuing opposition. However, even if you accept these arguments, they only get us to the right to oppose to oppose Brexit. They do not take us to the duty to oppose. How can we make that extra step?

To talk about the duties that we have as citizens is to raise the question of political obligation. Historically, the problem of political obligation has been reduced to the problem of the grounds of the duty to obey the duly authorised laws of the community. However, in 1993 Bhikhu Parekh (now Lord Parekh) published a seminal paper on the political obligations of citizens in a democracy. In that paper, he pointed out that the problem of political obligation was wrongly conceived, if it was thought of purely as a matter of the obligation to obey the law. In a democracy, obligations are more extensive and condition the way in which as individuals we conduct ourselves in relation to the public affairs of our community. I can do no better than quote the words of Parekh himself:

'... citizens have several obligations in addition to obeying the law. These include an obligation to take an active interest and to participate in the conduct of public affairs, to keep a critical eye on the activities of government, to speak up against the injustices of their society, to stand up for those too demoralized, confused and powerless to fight for themselves, and in general to create a rich and lively community ... citizens also have obligations to safeguard the integrity of the public realm, to do nothing to undermine the standards of public morality and debase the language of political discourse, to ensure truthfulness in public life, to pursue their interests consistently with those of the community and to conduct themselves with civility, moderation, courage and public spirit. ${ }^{5}$ 
In short, we need to live rightfully with others making our contribution to a political community that takes the common good and public reason seriously.

Notice how important it is in this respect not to see the democratic process as the contest of mere likings and dislikings. I made the point earlier that a necessary condition of the duty to oppose Brexit was that one thought the policy a mistake and deeply damaging to the common good of UK society. This goes beyond matters of personal interest, even personal legitimate interests. The mere fact that Brexit will raise the price of the German car you want to drive, the French or Italian holiday you plan to take or the or the ease with which you can visit your cousins in Warsaw is neither here nor there. These things may matter personally, and perhaps they may even give you a right to oppose Brexit, but they are not the ground of the claim that there is a duty to oppose Brexit. In short, responsible democratic citizens owe one another a duty of candour and judgement, and not a duty of acquiescence.

\section{What Does It Meant to Oppose?}

If there is a duty to oppose, what 'oppose' mean?

The duty to oppose Brexit is just that, a duty to oppose. I have not claimed that there is a duty, or even a right, to resist Brexit, to take up unlawful action or to engage in civil disobedience. I am not saying that Remainers should pay French farmers to herd flocks of sheep up Whitehall or to burn tyres on the M20. I am not advocating mass campaigns to log onto government web-sites to make them crash. I am not suggesting protestors should abseil into the House of Commons or that there should be mass a refusal to pay taxes. I am instead suggesting persistent and patient political opposition at every suitable point.

A centrepiece of my argument so far is that the referendum question never posed the alternative between the status quo and any one of the mutually inconsistent alternatives. We do not yet know which of the many possibilities will be realized, and only when we do will anyone be able to make a rational assessment of that alternative against continued membership. Of course, such assessments are always conjectural and subject to uncertainty. The consequences of different policies will always be contested. But there is a real difference between choosing between relatively well specified alternatives in policy terms and choosing between a status quo and a leap in the dark.

It follows from this logic that a goal of political opposition should be a second referendum on the terms of the negotiated settlement against continued membership. Such a possibility presupposes of course that the triggering of Article 50 does not lead to an irrevocable process, but there is good legal opinion that it does not, and in any case, we have no alternative but to make the best of a bad job. Some will say that a second referendum will be even more fractious and bad-tempered than the first, and that may well be. However, as a political matter, it is hard to see that the 2016 result can be reversed unless there is a constitutionally equivalent procedure, and if there were a second referendum in which the vote was to leave at least people like me could say that the popular choice was made on the basis of concrete alternatives. 
It may well be, of course, that an election takes place before the final negotiations with the EU are concluded. At present the UK government is trying to maintain three broad commitments: to maintain the 'best possible' access to the single market; to ensure that it has control over the number of people entitled to enter the UK; and to allow freedom to negotiate trade terms with non-EU countries under WTO terms. These three commitments correspond to the three main political forces currently operating on the Conservative Party: those of commerce and finance, who wish to retain single market access on the best terms; those of Conservative Party members, who share a vision of nostalgic Englishness; and those of the ideological global free-traders who think that the UK can become something like the Singapore of Europe. These three tendencies are in contradiction with one another. Ultimately, of course, a house divided against itself cannot stand, so it is possible that the contradictions will cause a collapse in confidence in the government of the day, the only solution to which is to call a general election.

If this were to happen, then the task of Brexit opposition would be to ensure that the terms of Brexit were front, centre and back of the campaign. However, this is unlikely to be a hard call, since in the words of the current House of Commons resolution, 'leaving the EU is the defining issue facing the UK'. Were a pro-Brexit government to emerge from that election, then in my view the case for a second referendum would be weakened, but not entirely eliminated. Much would depend on the relationship of seats to votes. If it were another 1922 , say, with some $56 \%$ of the seats on only $38 \%$ of the vote, then it would be different from a 1935 in which it was $70 \%$ of the seats on $54 \%$ of the vote.

As individual constituents, democratic citizens have a role to play in making sure that their elected representatives also maintain their democratic obligations. For those MPs who do think that leaving the EU would do serious damage to the common good of UK society, then, by the logic of the above argument, they have a duty to oppose Brexit. Suppose that the Supreme Court decides that triggering Article 50 cannot be done under the royal prerogative, but requires parliamentary approval. The democratic duty to oppose Brexit would apply to MPs, even to the point of voting against the triggering of Article 50. Sarah Olney committed herself to this course of action on winning the Richmond Park by-election. Given a judgement about the adverse consequences of Brexit, she and others are, I think, duty-bound to take this stance.

What obligations apply to members of the House of Lords? In some ways this is a more germane question than asking what obligations apply to members of the House of Commons. I anticipate that there would be a majority in the House of Commons for triggering Article 50. The position in the Lords would be more balanced and would incline to a majority against if peers voted solely on their individually considered judgement. However, a rejection of an Article 50 triggering by the Lords would bring about a constitutional crisis as serious as that brought about by the Lords' rejection of Lloyd George's 1909 budget. As with that rejection, the government would then have no alternative but to call a general election. At that point, there would be two issues facing the electorate: the process of leaving the European Union and the future of the House of Lords. My own view is that this combination of issues would muddy the waters of the election campaign, to the point where it 
would not be possible to make intelligent sense of the outcome as regards Brexit. Perhaps a large number of voters who are otherwise sceptical of leaving the EU would find it hard to accept an unelected chamber frustrating the decision of an elected house. So, I am inclined to think that, though they would be within their constitutional rights - and paradoxically might even be acting on their democratic obligations - to vote down the invocation of Article 50, it would not be a breach of those obligations if members of the Lords accepted the decision of the Commons, despite their better personal judgement. However, this is one of those issues that deserves more attention.

\section{Conclusions}

There are few issues in politics in which abstract theoretical issues interact as much with personal existential choice as the case of the EU referendum. The issue is one that combines the uncertainties of social and economic forecasting with deep normative questions about constitutions, the people, sovereignty, majority rule and individual democratic obligation. Of course, you may not share my pessimism about the likely consequences of the decision. The referendum result may have encouraged, rather than depressed you. If so, I hope you at least feel that, just as there is an obligation on Remainers to oppose Brexit, so there is an obligation on Leavers to defend it - and not just point to the result of the referendum as though all political debate was thereby ended.

\section{Acknowledgements}

I thank Robert Hazell for the invitation to speak at the Policy and Practice Seminar, and Richard Bellamy for comments on an earlier draft.

\footnotetext{
References

${ }^{1}$ https://www.heidisouthcambs.co.uk/constitutional-questions

2 Patrick Minford, 'Brexit Will Boost the Economy and Cut the Costs of BMWs and even Brie', The Sun, 15 March 2016.

https://www.thesun.co.uk/archives/politics/1086319/brexitwillboostoureconomyandcutthecostofbmws andevenbrie/

${ }^{3}$ H.L.A. Hart, The Concept of Law (Oxford: Clarendon, 1961), pp. 70-76. The same argument is made in the second edition (1994) at pp. 71-8.

${ }^{4}$ Kenneth O. May, 'A Set of Independent, Necessary and Sufficient Conditions for Simple Majority Decision', Econometrica, 20, (1952) pp. 680-84.

${ }^{5}$ Bhikhu Parekh, 'A Misconceived Discourse on Political Obligation', Political Studies, 41:2 (1993), pp. 236-51, at p. 243.
} 